\title{
ANTI-TNF AGENTS AS THERAPEUTIC CHOICE IN IMMUNE-MEDIATED INFLAMMATORY DISEASES: FOCUS ON ADALIMUMAB
}

\author{
A. ARMUZZI ${ }^{1}$, P. LIONETTI ${ }^{2}$, C. BLANDIZZI ${ }^{3}$, R. CAPORALI ${ }^{4}$, S. CHIMENTI ${ }^{5}$, L. CIMINO $^{6}$, P. $^{2}$ \\ GIONCHETTI $^{7}$, G. GIROLOMONI ${ }^{8}$, G. LAPADULA ${ }^{9}$, A. MARCHESONI ${ }^{10}$, A. MARCELLUSI ${ }^{11}$, \\ F.S. MENNINI ${ }^{11}$, C. SALVARANI ${ }^{12}$, R. CIMAZ ${ }^{13}$
}

'IBD Unit, Complesso Integrato Columbus, Catholic University, Via G. Moscati 31-33 00168 Rome, Italy; ' Gastroenterology Unit, Anna Meyer Children's Hospital, Department of Paediatrics, University of Firenze, Viale Peraccini 24, 50139, Firenze, Italy; ${ }^{3}$ Division of Pharmacology, Department of Clinical and Experimental Medicine, University of Pisa, Pisa, Italy; ${ }^{4}$ Chair and Division of Rheumatology, IRCCS Policlinico San Matteo Foundation, Pavia, Italy; 'Department of Dermatology, University of Rome "Tor Vergata", Rome, Italy; ${ }^{6}$ Ocular Immunology Unit, Ophthalmology, Unit, Arcispedale S Maria Nuova Reggio, Viale Risorgimento, 80 Reggio, Emilia,

42123 Italy, 'IBD Unit, Department of Medical and Surgical Sciences, S. Orsola-Malpighi Hospital, University of Bologna, Italy; ${ }^{8}$ Department of Medicine, Section of Dermatology and Venereology, University of Verona, Verona, Italy; ${ }^{9}$ Rheumatology Unit, Interdisciplinary Department of Medicine, Medical School, University of Bari, Italy; ${ }^{10} \mathrm{G}$. Pini Orthopaedic Institute, Piazza

A. Ferrari 1, 20122 Milano, Italy; "CEIS - Economic Evaluation and HTA (EEHTA), IGF Department, University of Tor Vergata, Rome, Italy; ${ }^{2}$ Rheumatology Unit, Department of Internal Medicine, Azienda Ospedaliera ASMN, Istituto di Ricovero e Cura a Carattere Scientifico, Viale Risorgimento 80, Reggio Emilia 42123, Italy; ${ }^{3}$ Department of Paediatrics, Rheumatology Unit, Anna Meyer Children's Hospital, University of Florence, Viale Pieraccini, Firenze 24 50139, Italy.

The complex pathogenesis of immune-mediated inflammatory diseases (IMIDs) has been extensively investigated and dysregulation of cytokines, such as tumour necrosis factor (TNF), has been shown to play a dominant role in the pathogenesis of various IMIDs, such as rheumatoid arthritis, ankylosing spondylitis, Crohn's disease, ulcerative colitis, psoriasis and psoriatic arthritis. The subsequent development of biological agents capable of blocking TNF has led to important advances in the pharmacotherapy of such diseases and confirmed the concept of a common pathophysiology among IMIDs with TNF having a predominant role. Five TNF inhibitors have currently been approved for treatment of one or more IMIDs; these include infliximab, etanercept, adalimumab, golimumab and certolizumab pegol. Given the similarities in the pathogenic background of IMIDs, one could expect that anti-TNF agents be similarly effective and with comparable tolerability profiles; however, this may not be the case. Structural and pharmacological differences among the anti-TNF drugs are likely to result in differences in efficacy and tolerability among the agents in the different IMIDs, together with differences in potency, therapeutic dose ranges, dosing regimens, administration routes, and propensity for immunogenicity. Among the five TNF inhibitors approved for treatment of IMIDs, adalimumab has

\section{Keywords: Tumour necrosis factor (TNF), immune-mediated disorders, anti-TNF therapy}

Mailing address:

Dr Paolo Lionetti, Gastroenterology Unit,

Anna Meyer Children's Hospital,

Department of Paediatrics, University of Firenze,

Viale Peraccini 24, 50139, Firenze, Italy.

Tel: 0555662488 ;

Email: paolo.lionetti@unifi.it

0394-6320 (2014)

Copyright (1) by BIOLIFE, s.a.s. This publication and/or article is for individual use only and may not be further reproduced without written permission from the copyright holder. Unauthorized reproduction may result in financial and other penalties DISCLOSURE: ALL AUTHORS REPORT NO CONFLICTS OF INTEREST RELEVANT TO THIS ARTICLE. 
the widest range of indications. Data from controlled clinical trials of adalimumab, showing its excellent efficacy and tolerability in a wide range of indications, are supported by real-world long-term data from observational studies, which confirm the value of adalimumab as a suitable choice in the management of IMIDs.

In recent years, the complex pathogenesis of immune-mediated inflammatory diseases (IMIDs) have been elucidated and dysregulation of cytokines has been shown to play a major role. Consequently, treatments for IMIDs have moved away from an approach mainly based on symptom relief (i.e. analgesics, steroids, and non-steroidal anti-inflammatory drugs [NSAIDs] such as cyclooxygenase- 2 inhibitors) to a mechanism-based strategy, in which biological therapies target specific dysregulated proteins or cell receptors that have been shown to play a key role in the altered immune response underlying these disorders (1). As a result, the traditional symptom-based approach meant that individual chronic inflammatory diseases were treated by the specialist for that particular organ, whereas a mechanism-based strategy demands a more holistic multi-disciplinary approach.

Over expression of tumour necrosis factor (TNF) has been shown to play a dominant role in the pathogenesis of various IMIDs, such as rheumatoid arthritis (RA), ankylosing spondylitis (AS), Crohn's disease, ulcerative colitis (UC), psoriasis and psoriatic arthritis (PsA). In addition to evidence from mechanistic studies, pointing out the common pathogenesis and role of TNF among IMIDs, findings from epidemiological and genetic studies support the theory that IMIDs are related disorders, with a common genetic susceptibility, thus explaining the co-occurrence or 'genetic overlap' and familial patterns of these diseases (2-6).

The subsequent development of biological agents able to block TNF has led to important advances in the pharmacotherapy of such diseases (7). The effectiveness of targeted anti-TNF therapy in many different IMIDs has confirmed, indeed, the concept of a common pathogenesis, with TNF $\alpha$ having a central role (7). TNF inhibitors have been shown to promote dramatic clinical remission and improved quality of life (QoL) even in patients with inadequate response to conventional pharmacotherapy. They are also well tolerated, can prevent disease progression, and in many cases they have been shown to reverse the target organ damage in different disorders (7-13).

Five TNF inhibitors have currently been approved for the treatment of one or more IMIDs; these include infliximab, etanercept, adalimumab, golimumab and certolizumab pegol. Each agent has been approved for specific therapeutic indications, some of which coincide. Among the available antiTNF agents, adalimumab has received regulatory approval in nine IMID indications to date. As such, it has the widest approved use of all biological agents and could, therefore, be best suited for treatment of these combined and co-occurring disorders.

\section{Objective and methodology}

The aim of this narrative review is to review pharmacological and clinical data on the differences among the available anti-TNF agents, as well as to review clinical trials and real-world data on the use of adalimumab in the treatment of IMIDs. Combined automated and manual literature searches were performed on PubMed using the search terms 'antiTNF'/'anti-TNF-alpha [ $\alpha]^{\prime} /{ }^{\prime}$ TNF inhibitor'/'TNFalpha $[\alpha]$ inhibitor' AND ('rheumatoid arthritis' OR psoriatic arthritis' OR 'psoriasis' OR 'axial spondyloarthropathy' OR 'ankylosing spondylitis' OR 'Crohn's disease' OR 'ulcerative colitis' OR 'juvenile idiopathic arthritis'). Appropriate papers for this review were manually selected from the search results and the bibliographies of previous review articles.

\section{Differences among anti-TNF agents Structural differences}

Anti-TNF drugs are either whole antibodies (infliximab, adalimumab and golimumab) or contain fragments of antibody in their structure (etanercept and certolizumab). Antibody structure (an Fc domain connected to two antigen binding Fab' domains) means that it can bind two molecules of the same antigen simultaneously. The Fc domain interacts with specific receptors, designated as $\mathrm{Fc}-\mathrm{Rn}$ and $\mathrm{Fc} \gamma-\mathrm{R}$ (14). Fc-Rn is expressed mainly on endothelial cells of blood vessels, enabling antibodies to adhere 
to the inner surface of vessels and then return to the circulation in an active form. In this way, vascular endothelium acts as a depot to prolong the half-life of circulating antibodies. Fc $\gamma-\mathrm{R}$ receptor is expressed on various cell populations and mediates phagocytosis, production of cytokines or antibodies, complementdependent cytotoxicity (CDC), antibody-dependent cell cytotoxicity (ADCC) and degranulation of mast cells or granulocytes $(15,16)$.

Being whole $\operatorname{IgG}_{1}$ monoclonal antibodies, infliximab, adalimumab and golimumab, bivalently bind TNF, to form multimeric 'antigen-antibody' complexes. Adalimumab and golimumab are fully human monoclonal antibodies $(17,18)$, whereas infliximab is a mouse-human chimeric monoclonal antibody (19). Etanercept is the only soluble TNF inhibitor consisting of a constant $\mathrm{Fc}$ fragment of human $\operatorname{IgG}_{1}$ connected via a hinge region to two extracellular human TNF receptor (TNFR) domains (20). Unlike infliximab, adalimumab and golimumab, etanercept forms a monovalent bond with TNF, likely because of a lack of flexibility of the hinge region. Certolizumab pegol consists of single $\operatorname{IgG}_{1}$ Fab' fragment of a humanized monoclonal antibody bound to two $20-\mathrm{kD}$ polyethylene glycol chains; the resulting expanded molecular mass increases the plasma half-life of the drug (21). Since it is not equipped with an $\mathrm{Fc}$ region, certolizumab interacts with TNF in a monovalent fashion $(15,22)$.

TNF exists either as a soluble TNF (sTNF) or a transmembrane TNF (tmTNF) exposed on the surface of TNF-expressing cells. All anti-TNF agents bind to and neutralize sTNF and exert different effects on tmTNF-expressing cells, but differences in affinity and avidity for STNF and tmTNF have been observed (23). Differences in the molecular structures of antiTNF drugs result in differences in pharmacokinetic and pharmacodynamic profiles, as described below, and give rise to variations in the anti-TNF effect on cell apoptosis, $\mathrm{CDC}$ and $\mathrm{ADCC}$ (23).

\section{Pharmacodynamic differences}

The most significant pharmacodynamic differences among anti-TNF drugs may be grouped into two main categories: 1) the ability to form complexes and 2) the presence or absence of an Fc region.

\section{Ability to form complexes}

A differential ability to establish links with the divalent or monovalently bound TNF determines whether large or small drug-TNF complexes are formed and influences their ability to activate reverse signalling processes (23). Large molecular complexes, generated by binding of TNF with infliximab, adalimumab or golimumab, allow: a) high stability of the drug-sTNF complex; b) faster clearance of these complexes from the bloodstream; c) slower dissociation of STNF from the drug (this property translates into a reduced ability of sTNF to be released from the antibody binding, to return free in the bloodstream and to regain its pro-inflammatory activity); d) a greater ability to activate processes of reverse signalling by tmTNF, resulting in an enhancement of the anti-inflammatory activity. By contrast, small complexes, formed when sTNF binds with etanercept or certolizumab, are characterized by: a) reduced stability; b) slow rate of removal from the bloodstream; c) high speed of dissociation of sTNF from the drug with reacquisition of proinflammatory activity; d) complexes of tmTNF with etanercept or certolizumab show less or no ability to evoke anti-inflammatory processes through reverse signalling $(22,24)$.

\section{Presence or absence of $F c$ region}

The presence or absence of the antibody Fc region in the drug molecule determines whether the drug can activate Fc-dependent effects, including $\mathrm{CDC}$ and $\mathrm{ADCC}(22,24)$.

Different propensities to activate $\mathrm{CDC}$ and ADCC may explain the differences in clinical effects observed with different anti-TNF agents, with those also having $\mathrm{CDC}$ and $\mathrm{ADCC}$ activity being more effective clinically than those that only neutralise TNF.

Since infliximab, adalimumab and golimumab are equipped with a complete $\mathrm{Fc}$ region, they can interact with Fc $\gamma$-R and activate Fc-dependent effects, including $C D C$ and $A D C C$. These drugs also interact with $\mathrm{Fc}-\mathrm{Rn}$, allowing them to remain in circulation, or extend their plasma half-life. Etanercept, despite being equipped with an $\mathrm{Fc}$ region, does not have the $\mathrm{CHl}$ domain, and this feature seems to explain its low propensity to induce $\mathrm{CDC}$. Moreover, the Fc region of etanercept shows a low affinity for $\mathrm{Fc}-\mathrm{Rn}$, 
and this could explain its shorter plasma half-life. Certolizumab is devoid of an Fc region and therefore cannot induce $\operatorname{CDC}$ or $\operatorname{ADCC}(25,26)$.

\section{Pharmacokinetic differences}

The pharmacokinetic profiles of anti-TNF in humans are difficult to compare due mainly to the lack of direct comparative studies and also because of the different dosages, routes and frequencies of administration. Nevertheless, some authors have used algorithms to extrapolate the pharmacokinetic profiles of these drugs at the steady state in order to allow comparisons among them. Infliximab, being administered intravenously, reaches high peak plasma concentrations $\left(\mathrm{C}_{\max } ; 118-192 \mathrm{mg} / \mathrm{L}\right)$ in approximately 7 days $\left(\mathrm{T}_{\max }\right)$, followed by marked reductions in circulating levels to $<1 \mathrm{mg} / \mathrm{L}$ just prior to administration of the next dose (trough serum concentration). By contrast, adalimumab, golimumab, etanercept and certolizumab, being administered by subcutaneous injection, reach lower $\mathrm{C}_{\max }$ (4.7-7.7, $5-6,1.1-2.4$, and $43-49 \mathrm{mg} / \mathrm{L}$, respectively) in shorter $\mathrm{T}_{\max }$ (approximately 5.5, 2-6, 2.1-3 and 2.27.1 days, respectively). Although $\mathrm{C}_{\max }$ are lower than those achievable with infliximab, they are subject to less fluctuation between one administration and the next. Another important parameter, which affects the duration of the anti-TNF effect, is the long plasma half-life $\left(t_{1 / 2}\right)$, which is an index of the propensity of a drug to remain in the bloodstream. Although published data are heterogeneous (infliximab, 7.712 days; adalimumab, 10-20 days; golimumab, 7-20 days; etanercept, 3-4 days; and certolizumab, 14 days), etanercept's shorter half-life than the other anti-TNF agents may be due to its low binding affinity for vascular endothelial Fc-Rn receptors (24, 26). The lack of a Fc region prevents certolizumab from interacting with the vascular endothelial Fc-Rn receptors (15). This should favour blood clearance of certolizumab with a faster subsequent reduction of its plasma half-life. However, this problem has been solved via the addition of two PEG chains, which allow the compound to remain in the blood circulation with a plasma half-life comparable to that of infliximab, adalimumab and golimumab.

\section{Differences in efficacy}

Since TNF has a central role in the pathogenesis and pathophysiology of IMIDs, one would expect that all five anti-TNF agents - adalimumab, etanercept, infliximab, certolizumab pegol and golimumab - would be similarly effective in the treatment of patients with any IMID; however, this does not appear be the case. Among the five agents, although infliximab and etanercept were introduced first, adalimumab has been shown to be effective for the widest range of indications. Within specific indications, direct head-to-head comparisons of efficacy are lacking (27) and data on the differences in clinical efficacy among the anti-TNF drugs by indirect comparisons are not reliable.

Not surprisingly, most data have been published for RA. A large Bayesian meta-analysis of studies of biological agents in RA (28) showed differences in efficacy of anti-TNF drugs used in combination with the disease-modifying anti-rheumatic drug (DMARD) methotrexate (MTX). In this analysis, etanercept was significantly more effective in improving American College of Rheumatology (ACR) 20/50/70 outcomes as compared with adalimumab and infliximab, without significant differences between etanercept and certolizumab pegol (28). However, an indirect comparison of the efficacy of eight biologics (including certolizumab pegol, infliximab, etanercept, adalimumab and golimumab) in RA, based on ACR50 outcome, showed that the efficacy among the agents was not significantly different, although all were significantly more effective than MTX and placebo (29). Another systematic review showed that the efficacy of all five anti-TNF agents was significantly higher than placebo but similar to MTX, and that the anti-TNF/ MTX combination was superior to either MTX or TNF-blocker alone, without differences among the anti-TNF agents (30). No difference in efficacy was also shown in another systematic indirect comparison (31).

The mechanism for increased efficacy of antiTNF agents with MTX versus anti-TNF alone is not clear, but greater longer-term effectiveness with the combination may be due to a reduced likelihood of anti-drug antibody (ADA) formation with adjunctive MTX; this is certainly observed with infliximab therapy. This issue is discussed in more detail in the section entitled 'Advantages of combination therapy with MTX' below. 
A dose-response meta-analysis, performed for quantifying the relative efficacy of biologics in RA, showed that, although all anti-TNF displayed a similar dose-response relationship, significant differences in efficacy among the anti-TNF were observed due to differences in the clinical dose ranges available: at the suggested starting dose, golimumab was the least efficacious, followed by infliximab, adalimumab, etanercept, and certolizumab (32).

Some data suggest that the TNF inhibitory effect varies among the agents, translating into different consequences for the highly complex pathogenic mechanisms involved in the various forms of IMID. Differences in the efficacy and tolerability among the anti-TNF agents in different IMIDs are likely to depend on structural and pharmacological differences among the agents.

\section{Administration and regimen differences}

Anti-TNF agents are given either as subcutaneous injection (etanercept, adalimumab, certolizumab and golimumab) or intravenously (infliximab). Although the intravenous infusion of infliximab has to be performed at the clinical or infusion centre, it only has to be administered once every 4-8 weeks. Etanercept, adalimumab, certolizumab and golimumab can be self-administered, but they are given more frequently (once or twice a week for etanercept, every 2 weeks for adalimumab and certolizumab, and every 4 weeks for golimumab).

Patients with AS were shown to appreciate having a choice in their anti-TNF therapy and cited different reasons for choosing intravenous or subcutaneous therapies (33). For infliximab, patients reported a reduced frequency of injections, administration by a trained professional and use of infusion time for leisure activities as the reasons for their preference, whereas for subcutaneous anti-TNF drugs, patients cited flexibility with timing of treatment, shortened administration time and convenience as the main reasons for their choice (33). In RA patients, results from the RIVIERA survey - a questionnaire-based study investigating patient preferences of antiTNF therapies in RA - showed that the treatment choice was important to patients and approximately half preferred intravenous and half subcutaneous administration (34). Reasons for choosing intravenous therapy were safety and reassuring physician presence, whereas reasons for choosing subcutaneous therapy were convenience and home treatment (34). Generally younger patients prefer self-administration and older patients prefer to visit a clinic (35). In patients with inflammatory bowel disease (IBD), two-thirds indicated a preference for intravenous or subcutaneous anti-TNF, whereas one-third of patients did not indicate a preference for either, and a trend towards a preference for infliximab versus adalimumab was reported; most of the patients who preferred infliximab did not like the idea of self-injecting, and most patients who preferred adalimumab appreciated the convenience of injecting at home; other reasons cited for the choice were the frequency of administration, mode of administration, or differing 'times in the marketplace'; infliximab has been on the market for a longer period of time in Crohn's disease than adalimumab (36).

\section{Differences in immunogenicity}

Although current evidence for differences in efficacy among anti-TNF agents is inconsistent, such differences tend to emerge when the therapeutic response to one anti-TNF agent is lost over time, but patients retain the ability to respond to other drugs of the same class $(15,26)$. A systematic review of 28 studies showed an improvement in effectiveness with a second anti-TNF agent (adalimumab, etanercept or infliximab) as compared with the therapeutic response achieved before switching, in patients who had discontinued a previous TNF inhibitor (27). The increasing lack of therapeutic response over time is thought to depend mainly on the formation of ADAs - a process that has been reported with many biological drugs and has been associated with all five anti-TNF agents, although with varying degrees of incidence, depending on the molecule and disease being considered (37). The immunogenicity displayed by adalimumab and infliximab appears to be linked to subtherapeutic serum drug levels and a loss of clinical response, while for etanercept, golimumab and certolizumab, data on immunogenicity are quite limited (38). However, based on current evidence, immune crossreactivity among anti-TNF drugs does not appear to occur. Additional research, aimed at assessing the immunogenicity of anti-TNF drugs (39), determining 
optimal treatment regimens and the concomitant use of DMARDs e.g. MTX and immunosuppressants, to minimize ADA formation or investigating the use of neutralizing immunotherapy to reduce the likelihood of ADA formation, is presently ongoing (37).

\section{Differences in safety profile}

Among the five TNF inhibitors approved for treatment of one or more IMIDs - infliximab, etanercept, adalimumab, golimumab and certolizumab pegol - most tolerability issues appear to be class effects (e.g. increased risk of some malignancies, serious infections and tuberculosis reactivation (40)), and there are very few clinically relevant differences among these agents apart from those related to the administration (e.g. infusion reaction with infliximab); however, data on certolizumab pegol and golimumab are limited (41). Findings from a recent meta-analysis suggest that etanercept may have the best tolerability profile in RA (30); tuberculosis and other granulomatous infections may occur more frequently with monoclonal anti-TNF antibodies, such as infliximab and adalimumab, than with soluble TNF receptors such as etanercept (42). Demyelination has been reported with etanercept, infliximab and adalimumab and is likely to occur also with the newer agents. Therefore, anti-TNF agents are contraindicated in patients with multiple sclerosis (41). Screening is advised to identify patients with multiple sclerosis, other demyelinating diseases, latent tuberculosis, HIV and hepatitis infection, to allow a risk/benefit analysis to be performed in the individual patient (41). Long-term safety data are limited even for etanercept, infliximab and adalimumab in RA (43) and interpreting long-term safety data is complicated by the fact that the same adverse events (AEs) are noted to be elevated in patients with autoimmune disease even in those not receiving biological therapy (44). All agents appear to have a propensity to trigger the development of anti-nuclear antibodies (ANAs) and double-stranded DNA antibodies (dsDNA-Abs) as well as to cause auto-immune diseases such as lupus-like disease or vasculitis, but the risk may be higher with infliximab (41).

All the anti-TNF agents are thought to be safe, at least for short-term therapy, in early stage pregnancy (45); however, they cross the placenta from the end of the second trimester, and, due to some reports of increased infection rates in children exposed in utero and concerns about the impact on the developing immune system, experts have suggested that antiTNF drug therapy should be stopped during the second trimester (45).

\section{Advantages of combination therapy with MTX}

All anti-TNF agents can be given as monotherapy in patients unresponsive to or unable to tolerate MTX (apart from infliximab and golimumab in RA which must be given with MTX). In RA, biological therapy plus MTX has been shown to be more effective than MTX alone, even in patients with an inadequate response to MTX prior to initiation of the biological therapy $(46,47)$. The advantages of combination therapy with MTX have also been observed in patients with early RA with minimal or no previous MTX treatment (48).

Although the mechanism is not known, concomitant use of MTX appears to reduce the immunogenicity of the anti-TNF agent and thus the risk of ADA formation $(49,50)$. Due to the particularly high risk of immunogenicity reported with infliximab in RA, concomitant use of MTX is required, and this combination appears to reduce the need for dose escalation over time (51).

Evidence comparing efficacy among the antiTNF drugs with MTX is limited, but a Bayesian mixed-treatment comparison of the efficacy of anti-TNF agents in RA patients, who did not previously respond to MTX alone, highlighted some differences. In particular, using ACR 20/50 and Health Assessment Questionnaire [HAQ] scores, etanercept was more effective than infliximab and golimumab, and certolizumab was more effective than infliximab and adalimumab (52). Analysis of ACR outcomes showed an improved efficacy of certolizumab versus golimumab, and HAQ analysis showed that adalimumab, certolizumab, etanercept and golimumab were superior to infliximab, and etanercept displayed higher efficacy as compared with adalimumab (52).

\section{Evidence for efficacy of adalimumab in IMIDs}

The pivotal randomized controlled trials (RCTs) of adalimumab in all approved indications are summarised in Table 1. 
Controlled clinical trials

\section{Rheumatoid arthritis}

In a 1-year multicentre study, adalimumab plus MTX was more effective than MTX alone at inhibiting the progression of structural joint damage, reducing the signs and symptoms, and improving physical function in 619 patients with active RA who had an inadequate response to MTX (53). Similarly, in the 1-year PREMIER study the combination therapy with adalimumab plus MTX was more effective in all outcomes measured than MTX alone or adalimumab alone in patients with early, aggressive RA who had not previously received MTX treatment (54).

Juvenile idiopathic arthritis (juvenile rheumatoid arthritis)

In the 48-week DE038 study adalimumab plus MTX was more effective than MTX or adalimumab alone or placebo, and this combination was well tolerated in children aged 4 to 17 years with active juvenile RA who had previously received treatment with NSAIDs (55).

\section{Ankylosing spondylitis}

The Adalimumab Trial Evaluating Long-Term Efficacy and Safety in AS (ATLAS) study was a randomised, double-blind, placebo controlled, 24week trial in which adalimumab was shown to have significantly greater efficacy over 24 weeks versus placebo (56). Although the rates of AEs was higher with adalimumab as compared with placebo, the rates of infections was similar and most AEs were mild-to-moderate(56). The subsequent 2-year openlabel extension study showed that the efficacy was improved or maintained up to 2 years and that the long-term adalimumab treatment was well tolerated, without cases of tuberculosis, congestive heart failure, lupus-like symptoms, or demyelinating disease (57).

\section{Psoriatic arthritis}

In the ADEPT randomized, double blind, placebo-controlled study in 313 patients with active PsA, adalimumab significantly improved all efficacy variables including joint and skin symptoms, and disability; it counteracted also the structural changes as compared with placebo, and was well tolerated. In the long-term open-label extension of ADEPT, the clinical and radiographic efficacy of adalimumab was sustained and the risk-benefit profile in patients with PsA was favourable over the 2 years of treatment $(58,59)$.

\section{Psoriasis}

In the REVEAL study - a 52-week, multicentre trial - 1212 patients with chronic plaque psoriasis were randomized to receive adalimumab $(40 \mathrm{mg})$ or placebo every other week (eow) for the first 15 weeks, and then, depending on $\geq 75 \%$ improvement in PASI score, subjects were re-randomised to adalimumab or placebo $(60,61)$. A $\geq 75 \%$ improvement in PASI score was achieved in $71 \%$ of patients receiving adalimumab and only $7 \%$ in placebo recipients. A loss of response was then observed in $28 \%$ of the patients re-randomised to placebo and only 5\% treated with adalimumab (60).

In the 16-week CHAMPION study, 271 patients with moderate-to-severe chronic plaque psoriasis were treated with adalimumab, MTX or placebo; adalimumab was shown to provide superior efficacy and more rapid improvements as compared with either MTX or placebo, with similar patterns of tolerability (62).

\section{Crohn's disease}

In the CHARM study, conducted on 854 patients with moderate-to-severe Crohn's disease, the enrolled subjects received open-label adalimumab for 4 weeks and were then stratified by response, defined as a decrease in Crohn's Disease Activity Index (CDAI) of $\geq 70$ points from baseline, and randomized to adalimumab $40 \mathrm{mg}$ eow or weekly or placebo for additional 52 weeks. Rates of clinical remission (CDAI <150) were significantly higher with adalimumab versus placebo at 26 and 56 weeks of treatment, but no differences between the eow and weekly dose regimens were recorded (63). In a subgroup analysis of the CHARM trial, stratification by disease duration showed that adalimumab treatment resulted in greater remission rates than placebo over 1 year regardless of duration; in Crohn's disease patients treated for 3 years, the remission rates with adalimumab were the highest in patients with the shortest disease duration, and the incidence of serious AEs was also lower in this group (64). 
In the CLASSIC II trial, the efficacy of openlabel adalimumab for maintaining remission in Crohn's disease was evaluated in 55 patients who achieved remission with adalimumab in CLASSIC I $(n=299)(65)$. In these patients, the remission at week 56 was achieved by $79 \%$ with eow treatment, $83 \%$ with weekly adalimumab and $44 \%$ with placebo. In addition, 204 patients, who did not achieve remission, received open-label adalimumab $40 \mathrm{mg}$ eow and $46 \%$ achieved remission at week $56(65)$.

In the EXTEND trial, of 135 patients with moderate to severe ileocolonic Crohn's disease, those receiving adalimumab were significantly more likely to achieve and maintain muscosal healing and achieve clinical remission than those receiving placebo (66).

\section{Ulcerative colitis}

In the 1-year randomized, double-blind, placebo-controlled ULTRA 2 study, adalimumab was more effective than placebo in achieving and maintaining clinical remission. It was also well tolerated in patients with moderate-to-severe UC with an inadequate response to conventional steroid or immunosuppressant therapy (67). In a subgroup analysis of 248 patients treated with adalimumab, $123(49.6 \%)$ achieved a response at week 8 , and of these $30.9 \%$, achieved clinical remission at week 52 ; early response was a significant predictor of a positive outcome at 1 year (68).

\section{Observational clinical practice studies}

Findings from post-registration observational studies have substantially confirmed that the outcomes recorded in RCTs can legitimately be extrapolated to the patients managed in the clinical practice.

\section{Inflammatory bowel diseases}

An observational study in UC showed that adalimumab is effective in these patients (69). The Productivity Safety and Efficacy: Long-Term Results in AdaliMumab-Treated Patients With Crohn's Disease (PYRAMID study) - the largest and longest study of adalimumab in the management of moderate to severe Crohn's disease patients - is an ongoing observational 6-year safety study, started in September 2007 in 24 countries to investigate adalimumab safety in the long-term treatment of Crohn's disease (70). The 3-year data in 5080 patients (9249 cumulative patient-years exposure; median duration of exposure 1.66 years) have shown that adalimumab is well tolerated with low, stable $\mathrm{AE}$ rates between years 2 and 3, without observation of new clinical concerns or safety signals. Indeed, the rates of serious infections were lower in patients receiving adalimumab monotherapy as compared with those receiving concomitant immunosuppressants or concomitant corticosteroids and immunosuppressants (70).

Real-life data for effectiveness of adalimumab in UC have been obtained in a retrospective observational Italian study in 88 patients (71). Adalimumab was effective despite patients had highly active UC at the start of treatment and despite most of the patients had been previously treated with infliximab (71). These data support those obtained in an uncontrolled prospective study in which 20 patients with active UC, who had lost their therapeutic response or developed intolerance to infliximab, responded well to adalimumab (72).

A retrospective observational study assessed the need for adalimumab dose escalation and deescalation in a large cohort of 720 patients with active Crohn's disease. The results showed that dose escalation was required in $34 \%$ of patients and that it was successful in $67 \%$; subsequent de-escalation following the induction of therapeutic response was attempted in $54 \%$, and it was successful in $63 \%$; by this strategy, $71 \%$ of patients maintained a long-term response on adalimumab (73).

\section{Rheumatoid arthritis}

A German observational study, investigating the outcomes of adalimumab treatment for RA, showed that adalimumab had a significant impact on therapeutic success during routine clinical practice (74). Factors predictive of positive outcome included high baseline DAS28 and male gender, whereas a high baseline functional capacity was associated with reduced gains in functional capacity and older age; in addition multiple previous biologics were associated with a reduced likelihood of therapeutic response (74).

In the Research in Active Rheumatoid Arthritis (ReAct) study, adalimumab was shown to be effective 
in RA patients previously treated with etanercept or infliximab in clinical practice. The risk of serious infections was similar regardless of whether patients had received anti-TNF therapy or not (75). The study showed also that adalimumab was effective and well tolerated either alone or in combination with traditional DMARDs (76).

\section{Psoriasis}

In the long-term open-label extension of the PRIDE study on efficacy and safety of adalimumab for moderate to severe chronic plaque psoriasis, the rate of disease recurrence following adalimumab discontinuation and subsequent retreatment was investigated (77). Of 525 patients withdrawn from adalimumab therapy, 285 had stable psoriasis control. Of these, $178(62 \%)$ relapsed before the planned treatment reinitiation at 40 weeks off-therapy. However, over two-thirds of these patients regained clinical efficacy following treatment reinitiation (77).

A small observational, prospective study, comparing monthly versus bi-weekly adalimumab therapy in 17 patients with moderate-to-severe chronic plaque psoriasis who responded well to an initial 24-week course of standard adalimumab therapy, showed that both regimens achieved control (defined as PASI75) in most patients by week 24 and this effect was maintained up to week 60 (78).

\section{Registries}

Several national registries provide clinical data from the real-world setting. The main aim of rheumatology drug registers is drug safety; however, they also highlight other important issues that otherwise would be missed in RCTs, such as drug usage, real-life long-term effectiveness, the impact on QoL, the safety of adalimumab treatment in the clinical setting and related economic issues $(79,80)$.

A number of registries have examined the safety of anti-TNF agents. For example, the Research Axed on Tolerance of Biotherapies (RATIO) registry, which investigated the incidence of lymphoma and opportunistic infections in all indications, showed an increased risk of Legionella pneumophila infection, a higher risk of tuberculosis with infliximab and adalimumab, and higher rates of opportunistic infections and lymphoma with anti-TNF monoclonal antibodies versus etanercept (81).
In RA, the Dutch Rheumatoid Arthritis Monitoring (DREAM) registry compared the remission criteria used in clinical trials and showed that DAS $28<2.6$ and minimal disease activity criteria were achievable in clinical practice after 6 months of anti-TNF therapy, although a residual disease activity was likely to remain. ACR/EULAR remission criteria were less likely to leave residual disease activity, but they were less achievable in clinical practice (82). The analysis of DREAM data showed also that the risk of serious infections in patients with RA treated with adalimumab or infliximab was similar, while being higher than with etanercept (83). Significant predictors for developing a serious infection during anti-TNF therapy in RA patients were age, corticosteroid use, VAS pain, HAQ, TJC28 and the presence of comorbidities at baseline (84).

DANBIO is a Danish registry of biological treatments of RA in clinical practice. DANBIO data from 8 years of treatment were used for a direct comparison of treatment responses, remission rates, and drug adherence in patients with RA treated with adalimumab, etanercept, or infliximab (85). The analysis of data showed that infliximab had the lowest rates of treatment response, disease remission, and drug adherence, while adalimumab had the highest rates of treatment response and disease remission, and etanercept had the longest drug survival rates. The following factors were identified as negative predictors of a clinical response and remission: older age, low functional status, and concomitant prednisolone (85). Additional data from DANBIO showed significantly reduced radiographic progression with anti-TNF treatment as compared with previous DMARD treatment in 517 patients with RA (86).

Data from the GISEA registry were used to analyse the risk of serious infections with long-term anti-TNF therapy - adalimumab, etanercept and infliximab - in RA. Findings showed that anti-TNF therapy is associated with a small, but significant, risk of serious infections; predictors of risk were concomitant use of steroids, advanced age, and the anti-TNF agent - highest for infliximab (65.1/1000 patient-years), followed by adalimumab $(23.7 / 1000$ patient-years), and then etanercept (12.8/1000 patient-years) (87). GISEA data showed also that the 4-year global drug survival with adalimumab, 
Table 1. Pivotal clinical studies of adalimumab in immune-mediated disease

\begin{tabular}{|c|c|c|c|c|c|c|}
\hline $\begin{array}{l}\text { Reference (study } \\
\text { acronym) }\end{array}$ & Patients $(\mathbf{N})$ & Design & Treatment & Endpoints & Efficacy outcomes & Safety outcomes \\
\hline Keystone et al. (53) & $\begin{array}{l}\text { Active RA on } \\
\operatorname{MTX}(619)\end{array}$ & $\begin{array}{l}\text { R. DB. PC. } 1 \\
\text { year }\end{array}$ & $\begin{array}{l}\text { Adalimumab } 40 \\
\text { mg eow } \\
\text { Adalimumab } 20 \\
\text { mg qw } \\
\text { PBO }\end{array}$ & $\begin{array}{l}\text { Week } 52 \text { mTSS } \\
\text { Week } 24 \text { and } 52 \\
\geq 20 \% \text { improvement in } \\
\text { ACR20 } \\
\text { Week } 52 \mathrm{HAQ-} \\
\text { disability index }\end{array}$ & $\begin{array}{l}\text { Change in mTSS greater with } \\
\text { Adalimumab vs PBO; week } 24 \\
\text { ACR } 2063 \% \text { and } 61 \% \text { for } \\
\text { Adalimumab } 40 \text { and } 20 \text { vs } 30 \% \\
\text { with PBO; week } 52 \text { ACR } 20 \\
59 \% \text { and } 55 \% \text { for Adalimumab } \\
40 \text { and } 20 \text { vs } 24 \% \text { with PBO; } \\
\text { HAQ mean change }-0.59 \text { and - } \\
0.61 \text {, vs }-0.25 \\
\text { All } p \leq 0.001\end{array}$ & $\begin{array}{l}\text { AEs similar in } \\
\text { adalimumab and PBO; } \\
\text { serious infections } \\
\text { higher with } \\
\text { Adalimumab }(3.8 \%) \\
\text { vs PBO }(0.5 \%) ; \\
\text { p } \leq 0.02\end{array}$ \\
\hline $\begin{array}{l}\text { Breedveld et al. (54) } \\
\text { (PREMIER) }\end{array}$ & $\begin{array}{l}\text { Early aggressive } \\
\text { RA, MTX naïve } \\
(799)\end{array}$ & R, DB, 2 year & $\begin{array}{l}\text { Adalimumab } 40 \\
\text { mg eow + MTX } \\
\text { MTX alone } \\
\text { Adalimumab } 40 \\
\text { mg eow alone }\end{array}$ & $\begin{array}{l}\text { 1- and 2-year ACR50; } \\
\text { mean change in mTSS }\end{array}$ & $\begin{array}{l}\text { Combination therapy superior } \\
\text { to mono in all efficacy } \\
\text { outcomes measured: ACR50 } \\
62 \% \text {, vs } 46 \% \text { with MTX and } \\
41 \% \text { with Adalimumab alone } \\
(p<0.001 \text { for both); less } \\
\text { radiographic progression at } 1 \\
\text { and } 2 \text { yrs ( } \leq 0.002)\end{array}$ & $\begin{array}{l}\text { AE profiles were } \\
\text { similar in all } 3 \text { study } \\
\text { groups }\end{array}$ \\
\hline $\begin{array}{l}\text { Lovell et al. (55) } \\
\text { (DE038) }\end{array}$ & $\begin{array}{l}\text { Juvenile } \\
\text { rheumatoid } \\
\text { arthritis (poly- } \\
\text { articular) (171) }\end{array}$ & $\begin{array}{l}\mathrm{R}, \mathrm{PC}, 2 \text { years } \\
\text { DB weeks } 16 \text { - } \\
32 \text { based on } \\
\text { week } 16 \\
\text { response }\end{array}$ & $\begin{array}{l}\text { Adalimumab } 24 \\
\mathrm{mg} / \mathrm{m}^{2} \mathrm{BSA} \\
(\mathrm{max} 40 \mathrm{mg}) \\
\text { eow } \pm \mathrm{MTX} \\
\mathrm{PBO} \pm \mathrm{MTX}\end{array}$ & $\begin{array}{l}\text { Disease flares } \\
\text { Week } 16 \text { and } 32 \\
\text { ACRpedi30 }\end{array}$ & $\begin{array}{l}\text { Week-16 ACRpedi } 3074 \% \text { in } \\
\text { Adalimumab alone and } 94 \% \text { in } \\
\text { Adalimumab +MTX } \\
\text { Disease flares: } \\
\text { No MTX: } 43 \% \text { with } \\
\text { Adalimumab and } 71 \% \text { PBO } \\
\text { ( }=0.03 \text { ). } \\
\text { With MTX: } 37 \% \text { Adalimumab } \\
\text { and } 65 \% \text { PBO ( } \mathrm{p}=0.02 \text { ). } \\
\text { Week- } 48 \text { ACRpedi30: } \\
\text { With MTX - significantly } \\
\text { greater for ADA vs PBO } \\
\text { No MTX - No significant } \\
\text { differences between } \\
\text { Adalimumab and PBO }\end{array}$ & $\begin{array}{l}\text { Safety profiles similar } \\
\text { among groups }\end{array}$ \\
\hline $\begin{array}{l}\text { Van der Heijde et al. } \\
\text { (56) } \\
\text { (ATLAS) }\end{array}$ & $\begin{array}{l}\text { Ankylosing } \\
\text { spondylitis } \\
\text { (315) }\end{array}$ & $\begin{array}{l}R, D B, P C \text { for } \\
24 \text { weeks }\end{array}$ & $\begin{array}{l}\text { Adalimumab } 40 \\
\text { mg eow } \\
\text { PBO }\end{array}$ & $\begin{array}{l}\% \text { of pts with } \\
\text { ASAS20 at week } 12 \\
\text { ASAS20 and week } 24 \text {, } \\
\text { ASAS40, ASAS } \\
\text { partial remission, } \\
\text { individual ASAS } \\
\text { response components; } \\
\text { BASFI, BASDAI }\end{array}$ & $\begin{array}{l}\text { Week } 12 \text {, ASAS20: } 58.2 \% \\
\text { Adalimumab and } 20.6 \% \text { PBO } \\
(\mathrm{p}<0.001) \text {. Week } 12 \geq 50 \% \\
\text { improvement in BASDAI } \\
45.2 \% \text { with ADA and } 15.9 \% \\
\text { with PBO (p<0.001). ASAS } 40 \\
\text { and ASAS } 5 / 6 \text { response } \\
\text { significantly greater with } \\
\text { Adalimumab vs PBO at weeks } \\
12 \text { and } 24(\mathrm{p}<0.001) \text {. }\end{array}$ & $\begin{array}{l}\text { AE rate with } \\
\text { Adalimumab } 75.0 \% \\
\text { vs } 59.8 \% \text { with } \mathrm{PBO} \text {; } \\
\mathrm{p}<0.05 \text { ). } \\
\text { Most AEs were mild } \\
\text { or moderate in } \\
\text { severity. }\end{array}$ \\
\hline
\end{tabular}




\begin{tabular}{|c|c|c|c|c|c|c|}
\hline & & & & & $\begin{array}{l}\text { Partial remission greater with } \\
\text { Adalimumab vs PBO }(22.1 \% \\
\text { versus } 5.6 \% ; \mathrm{p}<0.001)\end{array}$ & \\
\hline $\begin{array}{l}\text { van der Heijde et al. } \\
\text { (57) } \\
\text { (ATLAS OL } \\
\text { extension) }\end{array}$ & $\begin{array}{l}\text { Ankylosing } \\
\text { spondylitis } \\
\text { (311) }\end{array}$ & OL for 2 years & $\begin{array}{l}\text { Adalimumab } 40 \\
\text { mg eow } \\
\text { PBO }\end{array}$ & $\begin{array}{l}\geq 20 \% \text { improvement in } \\
\text { ASAS20 } \\
\text { ASAS40, ASAS } \\
\text { partial remission, } \\
\text { individual ASAS } \\
\text { response components; } \\
\text { BASFI, BASDAI }\end{array}$ & $\begin{array}{l}\text { ASAS responses sustained } \\
\text { during long-term treatment; } \\
\text { ASAS20 64.5\%, ASAS40 } \\
50.6 \% \text { and ASAS partial } \\
\text { remission } 33.5 \% ; \\
\text { Changes in ASAS response } \\
\text { components sustained or } \\
\text { improved; } \\
\text { BASDAI and BASFI improved } \\
\text { over } 2 \text { years. }\end{array}$ & $\begin{array}{l}\text { Long-term safety } \\
\text { similar to short-term } \\
\text { profile - Adalimumab } \\
\text { well tolerated. No } \\
\text { cases of TB, CHF, } \\
\text { lupus-like symptoms, } \\
\text { or demyelinating } \\
\text { disease reported. }\end{array}$ \\
\hline $\begin{array}{l}\text { Mease et al. } 2005 \\
(58) \\
\text { (ADEPT) }\end{array}$ & $\begin{array}{l}\text { Psoriatic } \\
\text { arthritis (313) }\end{array}$ & $\begin{array}{l}\text { R, DB, PC } 24 \\
\text { weeks }\end{array}$ & $\begin{array}{l}\text { Adalimumab } 40 \\
\text { mg eow } \\
\text { PBO }\end{array}$ & $\begin{array}{l}\geq 20 \% \text { improvement in } \\
\text { ASAS20 } \\
\text { Change in mTSS; } \\
\text { measures of joint and } \\
\text { skin disease. disability } \\
\text { and QoL }\end{array}$ & $\begin{array}{l}\text { Week 12: ACR20 } 58 \% \text { with } \\
\text { Adalimumab and } 14 \% \text { with } \\
\text { PBO ( } p<0.001 \text { ). } \\
\text { Week 24: ACR20 response } \\
\text { rates similar to wk } 12 \text { and } \\
\text { change in the mTSS }-0.2 \text { with } \\
\text { Adalimumab and } 1.0 \text { with } \\
\text { PBO (p<0.001). } \\
\text { Week-24 PASI75 in } 59 \% \text { ADA } \\
\text { and } 1 \% \text { with PBO ( }<<0.001 \text { ). } \\
\text { Disability and QoL measures } \\
\text { significantly improved with } \\
\text { Adalimumab vs PBO. }\end{array}$ & $\begin{array}{l}\text { Adalimumab was } \\
\text { generally safe and } \\
\text { well-tolerated }\end{array}$ \\
\hline $\begin{array}{l}\text { Mease et al. } 2009 \\
\text { (59) } \\
\text { (ADEPT OL } \\
\text { extension) }\end{array}$ & $\begin{array}{l}\text { Psoriatic } \\
\text { arthritis (245) }\end{array}$ & OL 2 years & $\begin{array}{l}\text { Adalimumab } 40 \\
\text { mg eow } \\
\text { PBO }\end{array}$ & $\begin{array}{l}\text { ACR20/50/70; } \\
\text { measures of joint } \\
\text { disease and skin } \\
\text { disease, disability and } \\
\text { QoL, mTSS }\end{array}$ & $\begin{array}{l}\text { Compared with 24-week } \\
\text { responses, inhibition of } \\
\text { radiographic progression and } \\
\text { improvements in joint disease } \\
\text { were maintained during long- } \\
\text { term, open-label Adalimumab. } \\
\text { Improvements in skin disease } \\
\text { were maintained, with }>20 \% \text { of } \\
\text { pts achieving PASI } 100 \text {. }\end{array}$ & $\begin{array}{l}\text { The nature and } \\
\text { frequency of AEs } \\
\text { during long-term } \\
\text { Adalimumab were } \\
\text { consistent with short- } \\
\text { term treatment. }\end{array}$ \\
\hline $\begin{array}{l}\text { Menter et al. (60) } \\
\text { (REVEAL) }\end{array}$ & Psoriasis (1212) & $\begin{array}{l}\text { R, PC, DB for } \\
15 \text { weeks then } \\
\text { re-randomised } \\
\text { at week } 16 \\
\text { based on } \\
\text { PASI75 } \\
\text { response, } \\
\text { treated for I } \\
\text { year }\end{array}$ & $\begin{array}{l}\text { Adalimumab } 40 \\
\text { mg eow } \\
\text { PBO }\end{array}$ & $\begin{array}{l}\text { PASI75 at week } 16 \\
\text { Week } 33-52 \\
\text { proportion of pts with } \\
\text { lost response (<50\% } \\
\text { improvement in PASI } \\
\text { response and } \geq 6 \text {-point } \\
\text { increase in PASI score } \\
\text { from week 33) }\end{array}$ & $\begin{array}{l}\text { Week } 16 \text {, PASI } 7571 \% \text { with } \\
\text { Adalimumab and } 7 \% \text { with } \\
\text { PBO. } \\
\text { Weeks } 33 \text { to } 52 \text {, lost response } \\
\text { rate } 28 \% \text { with pts re- } \\
\text { randomised to PBO vs } 5 \% \text { with } \\
\text { continued Adalimumab. }\end{array}$ & - \\
\hline $\begin{array}{l}\text { Saurat et al. (62) } \\
\text { (CHAMPION) }\end{array}$ & Psoriasis (271) & $\begin{array}{l}\mathrm{R}, \mathrm{DB}, \mathrm{PC} 16 \\
\text { weeks }\end{array}$ & $\begin{array}{l}\text { Adalimumab } 80 \\
\text { mg then } 40 \mathrm{mg} \\
\text { eow } \\
\text { MTX } \\
\text { PBO }\end{array}$ & $\begin{array}{l}\text { Week 16, proportion } \\
\text { of pts achieving } \geq 75 \% \\
\text { improvement in } \\
\text { PASI } 75 \text {. }\end{array}$ & $\begin{array}{l}16 \text { weeks PASI } 75 \text { with } \\
\text { Adalimumab } 79.6 \% \text { and MTX } \\
35.5 \% \text { ( } \mathrm{p}<0.001 \text { vs. } \\
\text { Adalimumab) and PBO } 18.9 \% \\
\text { ( } \mathrm{p}<0.001 \text { vs. Adalimumab). } \\
\\
\text { Complete clearance of disease } \\
\text { rate } 16.7 \% \text { with Adalimumab, }\end{array}$ & $\begin{array}{l}\text { AEs similar across } \\
\text { treatment groups. }\end{array}$ \\
\hline
\end{tabular}




\begin{tabular}{|c|c|c|c|c|c|c|}
\hline & & & & & $\begin{array}{l}7.3 \% \text { with } \mathrm{MTX} \text { and } 1.9 \% \text { with } \\
\mathrm{PBO} \\
\text { Adalimumab } 57 \% \\
\text { improvement in mean PASI } \\
\text { observed at week } 4 \text {. }\end{array}$ & \\
\hline $\begin{array}{l}\text { Gordon et al. (61) } \\
\text { (REVEAL OL } \\
\text { extension) }\end{array}$ & Psoriasis & $\begin{array}{l}\text { OL extension } \\
\text { of pts } \\
\text { receiving } \\
\text { Adalimumab } \\
\text { in the DB } \\
\text { phase, groups } \\
\text { by response, } 3 \\
\text { year }\end{array}$ & $\begin{array}{l}\text { Adalimumab } \\
\text { from basetine to } \\
3 \text { yrs } \\
\text { Adalimumab } \\
\text { from week } 16 \text { to } \\
3 \text { years }\end{array}$ & $\begin{array}{l}\text { In pts on continuous } \\
\text { Adalimumab: } \\
\text { Efficacy according to } \\
\text { DB response: } \\
1) \geq 75 \% \text { improvement } \\
\text { in PASI } 75 \text { at weeks } \\
16 \text { and } 33 ; \\
(2)<\text { PASI } 75 \text { at week } \\
16 ; \\
\text { (3) } \geq \text { PASI } 75 \text { at week } \\
16 \text { with } 50-<75 \% \\
\text { improvement in PASI } \\
\text { score at week } 33 \text {. } \\
\text { 4) Pts who began } \\
\text { adalimumab after } 16 \\
\text { weeks PBO }\end{array}$ & $\begin{array}{l}\text { 1)\& 3) Efficacy was well } \\
\text { maintained over } 3 \text { years. } \\
\text { 2)Some pts achieved long-term } \\
\text { PASI } 75 \text { responses. } \\
\text { 4)Eflicacy consistent with } \\
\text { other } 3 \text { groups. }\end{array}$ & $\begin{array}{l}\text { AE rates were } \\
\text { consistent with those } \\
\text { during REVEAL. }\end{array}$ \\
\hline $\begin{array}{l}\text { Colombel et al.(63) } \\
\text { (CHARM) }\end{array}$ & $\begin{array}{l}\text { Crohn's disease } \\
(777)\end{array}$ & $\begin{array}{l}\text { OL induction } \\
0-4 \text { weeks } \\
\text { then DB. R to } \\
\text { week } 56\end{array}$ & $\begin{array}{l}\text { Adalimumab } 40 \\
\text { mg eow } \\
\text { Adalimumab } 40 \\
\text { mg qw } \\
\text { PBO }\end{array}$ & $\begin{array}{l}\text { Stratification by week } \\
4 \text { response: decrease } \\
\text { in CDAl of } \geq 70 \text { points } \\
\% \text { of week-4 } \\
\text { responders with CDAI } \\
<150 \text { (clinical } \\
\text { remission) at week } 26 \\
\text { and } 56 \text {. }\end{array}$ & $\begin{array}{l}\% \text { of responders in remission } \\
\text { significantly greater with } \\
\text { Adalimumab } 40 \text {-mg eow and } \\
40 \text {-mg weekly groups versus } \\
\text { PBO at week } 26 \text { ( } 40 \% .47 \% \text {. } \\
\text { and } 17 \% \text {, respectively; } \\
\text { p<0.001) and week } 56 \text { ( } 36 \% \text {, } \\
41 \% \text {, and } 12 \% \text {. respectively; } \\
\text { p }<0.0011 \text { ). } \\
\text { No significant differences in } \\
\text { efficacy between adalimumab } \\
\text { eow and weekly dose } \\
\text { regimens. }\end{array}$ & $\begin{array}{l}\text { Adalimumab was } \\
\text { well-tolerated }\end{array}$ \\
\hline $\begin{array}{l}\text { Schreiber et al. (64) } \\
\text { (CHARM subgroups } \\
\text { enrolled into } \\
\text { ADHERE follow-on } \\
\text { trial) }\end{array}$ & $\begin{array}{l}\text { Crohn s disease } \\
\text { (777) }\end{array}$ & $\begin{array}{l}\text { Subgroup } \\
\text { analysis by } \\
\text { disease } \\
\text { duration: } \\
3 \text { categories: } \\
<2(n=93) \text {. 2- } \\
<5(n=148) \text {, } \\
\text { and } \geq 5 \text { years } \\
(n=536)\end{array}$ & $\begin{array}{l}\text { Adalimumab } \\
\text { PBO }\end{array}$ & $\begin{array}{l}\text { Clinical remission and } \\
\text { response rates at } \\
\text { weeks } 26 \text { and } 56\end{array}$ & $\begin{array}{l}\text { Week } 56 \text { clinical remission } \\
\text { rates significantly greater for } \\
\text { Adalimumab vs PBO in all } 3 \\
\text { duration subgroups ( } 19 \% \\
\text { versus } 43 \% \text { for }<2 \text { years; } \\
\mathrm{p}=0.024 ; 13 \% \text { versus } 30 \% \text { for } \\
2 \text { to }<5 \text { years: } \mathrm{p}=0.028 ; 8 \% \\
\text { versus } 28 \% \text { for } \geq 5 \text { years, } \\
\mathrm{p}<0.001 \text { ). } \\
\text { Shorter duration significant } \\
\text { predictor for higher remission } \\
\text { rate in Adalimumab -treated } \\
\text { pts. }\end{array}$ & $\begin{array}{l}\text { SAEs with } \\
\text { Adalimumab lowest } \\
\text { with disease duration } \\
<2 \text { years. }\end{array}$ \\
\hline $\begin{array}{l}\text { Sandborn et al. }(\overline{65}) \\
\text { (CLASSIC II) }\end{array}$ & $\begin{array}{l}\text { Crohn's disease } \\
\text { (276) }\end{array}$ & $\begin{array}{l}\text { OL for } 2 \\
\text { weeks then pts } \\
\text { achieving } \\
\text { remission } \\
\text { entered R } \\
\text { phase and }\end{array}$ & $\begin{array}{l}\text { Adalimumab } 40 \\
\text { mg wk } I \text { and } 2 ; \\
\text { pts in remission } \\
\text { at weeks } 0 \text { and } 4 \\
\text { re-randomised to } \\
\text { Adalimumab } 40\end{array}$ & $\begin{array}{l}\text { Week } 56 \text { maintenance } \\
\text { of remission (CDAI } \\
<150)\end{array}$ & $\begin{array}{l}\text { Remission rates at week } 56: \\
\text { Randomised: } 79 \% \text { with } \\
\text { Adalimumab } 40 \mathrm{mg} \text { eow and } \\
83 \% 40 \mathrm{mg} \text { weekly and } 44 \%\end{array}$ & $\begin{array}{l}\text { Adalimumab } \\
\text { generally well- } \\
\text { tolerated in all pts. }\end{array}$ \\
\hline
\end{tabular}




\begin{tabular}{|c|c|c|c|c|c|c|}
\hline & & $\begin{array}{l}\text { those not } \\
\text { achieving } \\
\text { remission } \\
\text { continued on } \\
\text { OL ADA for } \\
56 \text { weeks }\end{array}$ & $\begin{array}{l}\text { mg eow, } 40 \mathrm{mg} \\
\text { weekly, or PBO } \\
\\
\text { Pts not in } \\
\text { remission: } \\
\text { Adalimumab } 40 \\
\text { mg eow; dose } \\
\text { increased to } 40 \\
\text { mg weekly on } \\
\text { non-response or } \\
\text { flare }\end{array}$ & & $\begin{array}{l}\text { PBO }(p<0.05) \\
\text { OL ADA: } 46 \%\end{array}$ & \\
\hline $\begin{array}{l}\text { Rutgeerts et al. (66) } \\
\text { (EXTEND) }\end{array}$ & $\begin{array}{l}\text { Moderate to } \\
\text { severe } \\
\text { iteocolonic } \\
\text { Crohn`s disease } \\
\text { (135) }\end{array}$ & $\begin{array}{l}\text { R, DB, PC } 52 \\
\text { weeks }\end{array}$ & $\begin{array}{l}\text { Induction } \\
\text { Adalimumab } \\
160 \mathrm{mg} \text { at week } \\
0 \text { and } 80 \mathrm{mg} \text { at } \\
\text { week } 2 \text { then } \\
\text { randomised to: } \\
\text { Adalimumab } 40 \\
\text { mg eow } \\
\text { PBO }\end{array}$ & $\begin{array}{l}\text { Mucosal healing at } \\
\text { week } 12\end{array}$ & $\begin{array}{l}\text { Mucosal healing: } \\
\text { Week 12: } 27 \% \text { Adalimumab } \\
\text { vs } 13 \% \text { PBO }(\mathrm{p}=0.056) \text {. } \\
\text { Week } 52: 24 \% \text { and } 0 \text {, } \\
\text { respectively ( } \mathrm{p}<0.001) \text {. } \\
\text { Week-12 remission rates } \\
\text { (CDEI): } 52 \% \text { for Adalimumab } \\
\text { and } 28 \% \text { for PBO ( } \mathrm{p}=0.006) \text {. } \\
\text { Week } 52: 28 \% \text { and } 3 \% \\
\text { ( }<<0.001) . \\
\text { Remission (CDAI) greater } \\
\text { among pts given continuous } \\
\text { Adalimumab vs PBO at weeks } \\
12(47 \% \text { vs } 28 \% ; \mathrm{p}=0.021) \text { and } \\
52(33 \% \text { vs } 9 \% ; \mathrm{p}-0.001) \text {. }\end{array}$ & $\begin{array}{l}5 \text { serious and } 3 \\
\text { opportunistic } \\
\text { infections }\end{array}$ \\
\hline $\begin{array}{l}\text { Sandborn et al (67) } \\
\text { (ULTRA 2) }\end{array}$ & $\begin{array}{l}\text { Ulcerative } \\
\text { colitis (494) }\end{array}$ & $\begin{array}{l}\text { R, DB, PC } 52 \\
\text { weeks }\end{array}$ & $\begin{array}{l}\text { Adalimumab } \\
160 \mathrm{mg} \text { week } 0 \text {, } \\
80 \mathrm{mg} \text { at week } 2 \text {. } \\
\text { then } 40 \mathrm{mg} \text { eow } \\
\text { PBO }\end{array}$ & $\begin{array}{l}\text { Remission at weeks } 8 \\
\text { and } 52\end{array}$ & $\begin{array}{l}\text { Overall remission rates: } \\
\text { Week } 8: 16.5 \% \text { Adalimumab } \\
\text { and } 9.3 \% \text { PBO }(\mathrm{p}=0.019) \\
\text { Week } 52: 17.3 \% \text { and } 8.5 \% \\
(\mathrm{p}=0.004) . \\
\text { Anti-TNF naive pts remission } \\
\text { rates: } \\
\text { Week- } 8: 21.3 \% \text { Adalimumab } \\
\text { and } 11 \% \text { PBO ( } \mathrm{p}=0.017) \\
\text { Week } 52: 22 \% \text { and } 12.4 \% \\
(\mathrm{p}=0.029) . \\
\text { Previously received anti-TNFs } \\
\text { remission rates: } \\
\text { Week } 8: 9.2 \% \text { Adalimumab } \\
\text { and } 6.9 \% \text { on PBO ( } \mathrm{p}=0.559) \\
\text { Week } 52: 10.2 \% \text { and } 3 \% \\
(\mathrm{p}=0.039) .\end{array}$ & $\begin{array}{l}\text { SAE rate } 12 \% \text { in both } \\
\text { groups } \\
\text { Serious infections in } \\
1.6 \% \text { Adalimumab } \\
\text { and } 1.9 \% \mathrm{PBO} \text {. }\end{array}$ \\
\hline $\begin{array}{l}\text { Sandbom et al (68) } \\
\text { (ULTRA } 2 \text { subgroup } \\
\text { analysis) }\end{array}$ & $\begin{array}{l}\text { Ulcerative } \\
\text { colitis; pts } \\
\text { receiving } \\
\text { Adalimumab } \\
\text { achieving } \\
\text { clinical response } \\
\text { at week } 8 \text { in } \\
\text { ULTRA } 2(123)\end{array}$ & $\begin{array}{l}\text { R, DB, PC } 52 \\
\text { weeks }\end{array}$ & $\begin{array}{l}\text { Adalimumab } \\
160 \mathrm{mg} \text { week } 0 \text {, } \\
80 \mathrm{mg} \text { at week } 2 \text {, } \\
\text { then } 40 \mathrm{mg} \text { eow } \\
\text { PBO }\end{array}$ & $\begin{array}{l}\text { Pts assessed for week } \\
52 \text { clinical remission, } \\
\text { clinical response, } \\
\text { mucosal healing, } \\
\text { steroid-free remission } \\
\text { and steroid } \\
\text { discontinuation rates, } \\
\text { overall and by prior } \\
\text { anti-TNF use. }\end{array}$ & $\begin{array}{l}\text { Clinical remission rate } 30.9 \% \\
\text { Clinical response rate } 49.6 \% \\
\text { Mucosal healing rate } 43.1 \% \\
\text { Responders using } \\
\text { corticosteroids }(\mathrm{N}=90), 21.1 \% \\
\text { achieved steroid-free remission } \\
\text { and } 37.8 \% \text { were steroid-free at } \\
\text { week } 52 . \\
\text { Adalimumab had positive } \\
\text { benefit/risk balance for week } 8 \\
\text { and } 52 \text { response or remission } \\
\text { without serious AEs or serious } \\
\text { infections. }\end{array}$ & $\begin{array}{l}\text { No safety concerns } \\
\text { were identified. }\end{array}$ \\
\hline
\end{tabular}

ACR, American College of Rheumatology; ACRPedi30, American College of Rheumatology Pediatric 30 response; AE, adverse event; ASAS, Ankylosing Spondylitis Disease Activity Score; BASDAI, Bath Ankylosing Spondylitis Disease Activity Index; BASFI, Bath Ankylosing Spondylitis Functional Index; BSA, body surface area; CDAI, Crohn's Disease Activity Index; DB, double-blind; eow, every other week; HAQ, Health Assessment Questionnaire; mTSS, modified total Sharp score; MTX, methotrexate; PC, placebo-controlled; Pts, patients; $q w$, every week; $R$, randomised; $R A$, rheumatoid arthritis; $S A E$, serious adverse event. PBO, Placebo; OL, open-label; TB, tuberculosis; CHF, congestive heart failure; CDEI, Crohn's Disease Endoscopic Index of Severity 
etanercept and infliximab was $<50 \%$, with etanercept having the best retention rate. Concomitant use of MTX was a strong predictor of adherence to antiTNF therapy (88).

Results from the US Consortium of Rheumatology Researchers of North America (CORRONA) registry have supported an early use of anti-TNF therapy, with disease duration being an independent predictor of remission in RA patients initiating therapy (89). A comparison of the effectiveness of adalimumab, etanercept and infliximab in biologically naive and switched RA patients showed no differences in the response or remission rates among the antiTNF drugs, although infliximab was associated with greater persistence in naive patients. In those who were switched to an anti-TNF, the response, remission and persistence were lower as compared with naive patients (90). In an analysis of data from the RADIUS registry, persistence with etanercept, infliximab and adalimumab were all similar with approximate rates of $50 \%$ for the first and secondline use (91).

The British Society for Rheumatology Biologics (BSRB) Register - launched in 2001 to monitor the real-world effectiveness and safety of anti-TNF agents and other biologics in RA, and then expanded to other indications - has produced a wide range of data on anti-TNF treatment (in comparison with a non-biologic DMARD control arm) in a range of indications including RA (92, 93), PsA (94), AS (95) and juvenile idiopathic arthritis (JIA) (96). In addition to providing long-term real-world effectiveness and safety data, the BSRB registry has also enabled the evaluation of anti-TNF switching patterns (92).

The TREAT registry was initiated to collect longterm safety data for infliximab and other therapies used in Crohn's disease. Data from more than 5 years' follow-up show an increased risk of serious infections in patients with moderate-severe disease, or treated with either steroids or infliximab or opioid analgesic. As far as risk of mortality is concerned, the higher and significant risk was associated either to age or steroids use or opioid analgesic use (97).

PSOCARE is an Italian registry programme initiated by AIFA (the Italian Medicines Agency) in 2004 and conducted in collaboration with both scientific dermatological societies (SIDeMaST and ADOI) and ADIPSO (an association of patients affected by psoriasis ) - designed to evaluate the realworld long-term outcomes of systemic treatment of psoriasis, including QoL, predictors of clinical response and other factors influencing treatment and outcomes (98-102). Published PSOCARE data suggest that biologic agents are becoming the treatment of choice due to their long-term efficacy and benign tolerability (100). Another PSOCARE data analysis has shown that higher body mass index of patients is associated with a reduction in early clinical response to systemic treatment (102) and, recently, Gisondi et al. reported that many systemic treatments used for long-term management of psoriasis affect a range of metabolic parameters, such as lipid and glucose levels, liver enzymes and renal markers; this has been noted particularly with the retinoid acitretin and cyclosporine, but also with methotrexate and biological agents (98).

Registries can also be used for comparison purposes. For example, a control cohort of RA patients receiving DMARD treatment from a Norwegian registry was compared with data on adalimumab therapy from the DE033 open-label extension study, and it was observed that patients with RA who received adalimumab experienced considerably longer periods of work and continuous employment than patients receiving DMARDs in the setting of clinical practice (103).

Another registry in patients with JIA - the Juvenile Idiopathic Arthritis Registry (STRIVE) is currently ongoing (http://clinicaltrials.gov/ct2/show/ NCT00783510).

\section{Future anti-TNF treatment strategies}

Anti-TNF agents have been used predominantly as second-line therapy in patients failing multiple DMARD therapy, but clinical data indicate greater clinical benefits when biologics are used earlier in the disease course as first-line therapy - resulting in a prevention of irreversible target organ damage in some patients, for example, in RA $(54,104)$ and IBD (8).

The OPTIMA study, conducted in 1032 patients with active early RA, demonstrated a clear benefit of initiating anti-TNF therapy early; the combination of adalimumab with MTX allowed to achieve higher ACR20/50/70 responses, more clinical remissions, greater mean reductions in disease activity, no radiographic progression, and normal functional 
status at 6 months as compared with MTX alone $(p<0.001$ for all) (104). The PREMIER study was a 2-year, randomized, double-blind clinical trial of combination therapy with adalimumab plus MTX versus MTX or adalimumab alone in 799 patients with early, aggressive RA (54). The results showed that, in patients who had not been previously treated with MTX, the initiation with a combination of adalimumab plus MTX was significantly superior to either MTX alone or adalimumab alone in improving signs and symptoms of disease, inhibiting radiographic progression, and promoting clinical remission; in addition, tolerability was similar in all treatment groups (54).

Recommendations for early treatment of RA from the EULAR guidelines are conservative and advocate MTX as first-line therapy in patients at risk of persistent or erosive disease based on its efficacy, safety profile, and on its beneficial outcomes in treatment combinations $(11,105)$. According to EULAR guidelines, biological therapy should be considered when poor prognostic factors are present or in patients with insufficient response to MTX and/or other traditional DMARDs, and the standard practice would be to start a TNF inhibitor in combination with MTX (11). With regard for biological therapy, guidelines emphasize the importance of a regular monitoring of disease activity and AEs in guiding the decisions on treatment choice and changes, and recommend a careful evaluation of the individual benefit/risk ratio for each patient (105). Although RA treatment guidelines advocate a tighter control of disease activity to prevent progression, many clinicians would prefer to use anti-TNF agents earlier in the disease course than treatment guidelines currently recommend $(106,107)$.

Recommendations for the use of biologics in early Crohn's disease state that, while data suggest that biologic therapies may be more effective in some patients, current evidence does not support a widespread early use of biologics in all patients. Early use of biologics should be considered on an individual basis in patients with Crohn's disease with a predictable severe disease course, such as those with extensive disease, severe rectal disease, young age, severe perianal diseases at diagnosis and need for steroids at diagnosis $(12,108)$.

When considering dermatological indications, currently there are no data or recommendations supporting the use of anti-TNF therapy in the early disease.

Although there are observational data identifying patients who may be more responsive to anti-TNF therapies (95) or more likely to succumb to infections (84), further clinical studies are required to identify patients most likely to benefit from anti-TNF therapy early in their disease course. Pharmacogenetic studies might be able to aid in such identification $(109,110)$.

\section{CONCLUSIONS}

Targeting TNF by means of biologic anti-TNF agents is one of several possible ways to bring the dysregulated immune system under control. This strategy offers effective therapeutic options with good tolerability in patients with IMIDs. Since TNF plays a central role in the pathogenesis and pathophysiology of all IMIDs, it is not surprising that five anti-TNF agents - adalimumab, etanercept, infliximab, certolizumab pegol and golimumab - have been shown to be effective in one or more IMIDs. Given the similarity in IMID pathology, one could expect that the anti-TNF agents would display similar patterns of effectiveness and have comparable tolerability profiles. However, this may not be the case. Structural and pharmacological differences among the anti-TNF agents are likely to result in differences in their efficacy and tolerability in the different IMIDs. Although there is no definitive evidence supporting differences in the clinical efficacy of the various anti-TNF drugs, clear differences in potency, therapeutic dose ranges, dosing, administration regimens, and propensity for immunogenicity do exist.

Among the five TNF inhibitors approved for treatment of IMIDs, adalimumab has the widest range of indications and is, therefore, best placed for treatment of co-occurring inflammatory disorders. Data from controlled clinical trials, showing an excellent efficacy and tolerability of adalimumab in a wide range of indications, supported by realworld long-term findings from observational studies, confirm the value of adalimumab as a suited choice in the management of IMIDs. Further clinical studies are required to identify patients who may be more responsive to anti-TNF therapies and those who are 
most likely to benefit from anti-TNF therapy early in the disease course, in order to ensure that treatment can be optimised and tailored to the individual patient.

\section{ACKNOWLEDGEMENTS}

Medical writing assistance was provided by Mary Hines on behalf of HPS, Health Publishing \& Services Srl, Milan. The assistance was supported by funding from AbbVie Srl, Italy.

$\mathrm{CB}$ has been member of advisory boards for Abbvie.

GG has received advisory/speaker honoraria and/or research funding from AbbVie, Almirall, Boehringer Ingelheim, Celgene, Dompè, Eli-Lilly, Galderma, GSK, Janssen, Leo Pharma, Otsuka, Merck-Serono, Maruho, MSD, Novartis and Pfizer.

AA has received consulting fees from Abbvie, Hospira, Lilly, MSD and lecture fees from Abbvie, Chiesi, Ferring, MSD, Nycomed and Otsuka.

$A M$ has received consulting fees and/or speaker fees from Abbvie, Pfizer, Merck, UCB.

$\mathrm{RC}$ has been member of advisory boards for Abbvie.

The other authors have no conflicts of interest to declare.

\section{REFERENCES}

1. Firestein G.S., M. Corr. Common mechanisms in immune-mediated inflammatory disease. J Rheumatol Suppl 2005; 73:8-13; discussion 29-30.

2. Robinson D., Jr., M. Hackett, J. Wong, A.B. Kimball, R. Cohen, M. Bala. Co-occurrence and comorbidities in patients with immune-mediated inflammatory disorders: an exploration using US healthcare claims data, 2001-2002. Curr Med Res Opin 2006; 22:9891000.

3. Yeh S., N.K. Karne, S.P. Kerkar et al. Ocular and systemic autoimmunity after successful tumorinfiltrating lymphocyte immunotherapy for recurrent, metastatic melanoma. Ophthalmology 2009; 116:981-89 el.

4. Cihakova D., N.R. Rose. Pathogenesis of myocarditis and dilated cardiomyopathy. Adv Immunol 2008; 99:95-114.
5. Lakomek H.J., A. Krause. [Treat-to-target (T2T) from the perspective of inpatient rheumatology]. $Z$ Rheumatol 2011; 70:656-63.

6. Callhoff J., A. Weiss, A. Zink, J. Listing. Impact of biologic therapy on functional status in patients with rheumatoid arthritis--a meta-analysis. Rheumatology (Oxford) 2013; 52:2127-2135.

7. Kuek A., B.L. Hazleman, A.J. Ostor. Immunemediated inflammatory diseases (IMIDs) and biologic therapy: a medical revolution. Postgrad Med J 2007; 83:251-60.

8. Blonski W., A.M. Buchner, G.R. Lichtenstein. Inflammatory bowel disease therapy: current stateof-the-art. Curr Opin Gastroenterol 2011; 27:346-57.

9. Furst D.E., E.C. Keystone, J. Braun et al. Updated consensus statement on biological agents for the treatment of rheumatic diseases, 2011. Ann Rheum Dis 2012; 71 Suppl 2:i2-45.

10. Abuzakouk M., C. Feighery, J. Jackson. Tumour necrosis factor blocking agents: a new therapeutic modality for inflammatory disorders. Br J Biomed Sci 2002; 59:173-9.

11. Bijlsma J.W. Optimal treatment of rheumatoid arthritis: EULAR recommendations for clinical practice. Pol Arch Med Wewn 2010; 120:347-53.

12. Orlando A., A. Armuzzi, C. Papi et al. The Italian Society of Gastroenterology (SIGE) and the Italian Group for the study of Inflammatory Bowel Disease (IG-IBD) Clinical Practice Guidelines: The use of tumor necrosis factor-alpha antagonist therapy in inflammatory bowel disease. Dig Liver Dis 2011; 43:1-20.

13. Watson K., K. Hyrich. The role of the British Society for Rheumatology Biologics Register (BSRBR) and the NICE guidelines for anti-TNF therapy. Musculoskeletal Care 2003; 1:58-64.

14. Woof J.M., D.R. Burton. Human antibody-Fc receptor interactions illuminated by crystal structures. Nat Rev Immunol 2004; 4:89-99.

15. Thalayasingam N., J.D. Isaacs. Anti-TNF therapy. Best practice \& research Clinical rheumatology 2011; 25:549-67.

16. Albanesi M., M. Daeron. The interactions of therapeutic antibodies with $\mathrm{Fc}$ receptors. Immunol Lett 2012; 143:20-7.

17. Shealy D., A. Cai, K. Staquet et al. Characterization 
of golimumab, a human monoclonal antibody specific for human tumor necrosis factor alpha. MAbs 2010:2.

18. Rau R. Adalimumab (a fully human anti-tumour necrosis factor alpha monoclonal antibody) in the treatment of active rheumatoid arthritis: the initial results of five trials. Ann Rheum Dis 2002; 61 Suppl 2:ii70-3.

19. Maini R., E.W. St Clair, F. Breedveld et al. Infliximab (chimeric anti-tumour necrosis factor alpha monoclonal antibody) versus placebo in rheumatoid arthritis patients receiving concomitant methotrexate: a randomised phase III trial. ATTRACT Study Group. Lancet 1999; 354:1932-9.

20. Haraoui B., V. Bykerk. Etanercept in the treatment of rheumatoid arthritis. Ther Clin Risk Manag 2007; 3:99-105.

21. Chimenti M.S., R. Saraceno, A. Chiricozzi, A. Giunta, S. Chimenti, R. Perricone. Profile of certolizumab and its potential in the treatment of psoriatic arthritis. Drug Des Devel Ther 2013; 7:339-48.

22. Taylor P.C. Pharmacology of TNF blockade in rheumatoid arthritis and other chronic inflammatory diseases. Curr Opin Pharmacol 2010; 10:308-15.

23. Benucci M., G. Saviola, M. Manfredi, P. SarziPuttini, F. Atzeni. Tumor necrosis factors blocking agents: analogies and differences. Acta Biomed 2012; 83:72-80.

24. Rigby W.F. Drug insight: different mechanisms of action of tumor necrosis factor antagonists-passiveaggressive behavior? Nat Clin Pract Rheumatol 2007; 3:227-33.

25. Mewar D., A.G. Wilson. Treatment of rheumatoid arthritis with tumour necrosis factor inhibitors. $\mathrm{Br} \mathrm{J}$ Pharmacol 2011; 162:785-91.

26. Tracey D., L. Klareskog, E.H. Sasso, J.G. Salfeld, P.P. Tak. Tumor necrosis factor antagonist mechanisms of action: a comprehensive review. Pharmacol Ther 2008; 117:244-79.

27. Malottki K., P. Barton, A. Tsourapas et al. Adalimumab, etanercept, infliximab, rituximab and abatacept for the treatment of rheumatoid arthritis after the failure of a tumour necrosis factor inhibitor: a systematic review and economic evaluation. Health Technol Assess 2011; 15:1-278.

28. Orme M.E., K.S. Macgilchrist, S. Mitchell, D. Spurden, A. Bird. Systematic review and network meta-analysis of combination and monotherapy treatments in disease-modifying antirheumatic drug-experienced patients with rheumatoid arthritis: analysis of American College of Rheumatology criteria scores 20, 50, and 70. Biologics 2012; 6:42964.

29. Devine E.B., R. Alfonso-Cristancho, S.D. Sullivan. Effectiveness of biologic therapies for rheumatoid arthritis: an indirect comparisons approach. Pharmacotherapy $2011 ; 31: 39-51$.

30. Aaltonen K.J., L.M. Virkki, A. Malmivaara, Y.T. Konttinen, D.C. Nordstrom, M. Blom. Systematic review and meta-analysis of the efficacy and safety of existing TNF blocking agents in treatment of rheumatoid arthritis. PLoS One 2012; 7:e30275.

31. Gallego-Galisteo M., A. Villa-Rubio, E. Alegredel Rey, E. Marquez-Fernandez, J.J. Ramos-Baez. Indirect comparison of biological treatments in refractory rheumatoid arthritis. J Clin Pharm Ther 2012; 37:301-7.

32. Mandema J.W., D.H. Salinger, S.W. Baumgartner, M.A. Gibbs. A dose-response meta-analysis for quantifying relative efficacy of biologics in rheumatoid arthritis. Clin Pharmacol Ther 2011; 90:828-35.

33. Fajri D.W., C.A. Brand, S.C. Dharmage, B.J. Martin, R.R. Buchanan, L. Schachna. What factors determine patients' preference for tumour necrosis factor inhibitors in ankylosing spondylitis? Clin Rheumatol 2009; 28:599-602.

34. Scarpato S., M. Antivalle, E.G. Favalli et al. Patient preferences in the choice of anti-TNF therapies in rheumatoid arthritis. Results from a questionnaire survey (RIVIERA study). Rheumatology (Oxford) 2010; 49:289-94.

35. Chilton F., R.A. Collett. Treatment choices, preferences and decision-making by patients with rheumatoid arthritis. Musculoskeletal Care 2008; $6: 1-14$.

36. Allen P.B., H. Lindsay, T.C. Tham. How do patients with inflammatory bowel disease want their biological therapy administered? BMC Gastroenterol $2010 ; 10: 1$.

37. Spinelli F.R., G. Valesini. Immunogenicity of antitumour necrosis factor drugs in rheumatic diseases. Clin Exp Rheumatol 2013; 31:954-963. 
38. van Schouwenburg P.A., T. Rispens, G.J. Wolbink. Immunogenicity of anti-TNF biologic therapies for rheumatoid arthritis. Nat Rev Rheumatol 2013; 9:164-72.

39. Garces S., M. Antunes, E. Benito-Garcia, J.C. da Silva, L. Aarden, J. Demengeot. A preliminary algorithm introducing immunogenicity assessment in the management of patients with RA receiving tumour necrosis factor inhibitor therapies. Ann Rheum Dis 2013 (Epub ahead of print).

40. Bongartz T., A.J. Sutton, M.J. Sweeting, I. Buchan, E.L. Matteson, V. Montori. Anti-TNF antibody therapy in rheumatoid arthritis and the risk of serious infections and malignancies: systematic review and meta-analysis of rare harmful effects in randomized controlled trials. Jama 2006; 295:2275-85.

41. Ding T., J. Ledingham, R. Luqmani et al. BSR and BHPR rheumatoid arthritis guidelines on safety of anti-TNF therapies. Rheumatology (Oxford) 2010; 49:2217-9.

42. Dixon W.G., K.L. Hyrich, K.D. Watson, M. Lunt, J. Galloway, A. Ustianowski, D.P. Symmons. Drug-specific risk of tuberculosis in patients with rheumatoid arthritis treated with anti-TNF therapy: results from the British Society for Rheumatology Biologics Register (BSRBR). Ann Rheum Dis 2010; 69:522-8.

43. Gartlehner G., R.A. Hansen, B.L. Jonas, P. Thieda, K.N. Lohr. The comparative efficacy and safety of biologics for the treatment of rheumatoid arthritis: a systematic review and metaanalysis. J Rheumatol 2006; 33:2398-408.

44. Onel K.B., K. Onel. Anti-tumor necrosis factor therapy and cancer risk in patients with autoimmune disorders. Arthritis Care Res (Hoboken) 2010; 62:1024-8.

45. Gisbert J.P., M. Chaparro. Safety of anti-TNF agents during pregnancy and breastfeeding in women with inflammatory bowel disease. Am J Gastroenterol 2013; 108:1426-38.

46. Nam J.L., K.L. Winthrop, R.F. van Vollenhoven et al. Current evidence for the management of rheumatoid arthritis with biological disease-modifying antirheumatic drugs: a systematic literature review informing the EULAR recommendations for the management of RA. Ann Rheum Dis 2010; 69:976-
86.

47. Pierreisnard A., N. Issa, T. Barnetche, C. Richez, T. Schaeverbeke. Meta-analysis of clinical and radiological efficacy of biologics in rheumatoid arthritis patients naive or inadequately responsive to methotrexate. Joint Bone Spine 2013; 80:386-92.

48. Kuriya B., E.V. Arkema, V.P. Bykerk, E.C. Keystone. Efficacy of initial methotrexate monotherapy versus combination therapy with a biological agent in early rheumatoid arthritis: a meta-analysis of clinical and radiographic remission. Ann Rheum Dis 2010; 69:1298-304.

49. Jani M., A. Barton, R.B. Warren, C.E. Griffiths, H. Chinoy. The role of DMARDs in reducing the immunogenicity of TNF inhibitors in chronic inflammatory diseases. Rheumatology (Oxford) 2014; 53:213-22.

50. Andrisani G., E. Gremese, L. Guidi et al. Achievement of sustained deep remission with adalimumab in a patient with both refractory ulcerative colitis and seronegative erosive rheumatoid arthritis. In press 2013.

51. Murdaca G., B.M. Colombo, F. Puppo. Adalimumab for the treatment of immune-mediated diseases: an update on old and recent indications. Drugs Today (Barc) 2011; 47:277-88.

52. Schmitz S., R. Adams, C.D. Walsh, M. Barry, O. FitzGerald. A mixed treatment comparison of the efficacy of anti-TNF agents in rheumatoid arthritis for methotrexate non-responders demonstrates differences between treatments: a Bayesian approach. Ann Rheum Dis 2012; 71:225-30.

53. Keystone E.C., A.F. Kavanaugh, J.T. Sharp et al. Radiographic, clinical, and functional outcomes of treatment with adalimumab (a human antitumor necrosis factor monoclonal antibody) in patients with active rheumatoid arthritis receiving concomitant methotrexate therapy: a randomized, placebo-controlled, 52-week trial. Arthritis Rheum 2004; 50:1400-11.

54. Breedveld F.C., M.H. Weisman, A.F. Kavanaugh et al. The PREMIER study: A multicenter, randomized, double-blind clinical trial of combination therapy with adalimumab plus methotrexate versus methotrexate alone or adalimumab alone in patients with early, aggressive rheumatoid arthritis who had 
not had previous methotrexate treatment. Arthritis Rheum 2006; 54:26-37.

55. Lovell D.J., N. Ruperto, S. Goodman et al. Adalimumab with or without methotrexate in juvenile rheumatoid arthritis. N Engl J Med 2008; 359:81020.

56. van der Heijde D., A. Kivitz, M.H. Schiff et al. Efficacy and safety of adalimumab in patients with ankylosing spondylitis: results of a multicenter, randomized, double-blind, placebo-controlled trial. Arthritis Rheum 2006; 54:2136-46.

57. van der Heijde D., M.H. Schiff, J. Sieper et al. Adalimumab effectiveness for the treatment of ankylosing spondylitis is maintained for up to 2 years: long-term results from the ATLAS trial. Ann Rheum Dis 2009, 68:922-9.

58. Mease P.J., D.D. Gladman, C.T. Ritchlin et al. Adalimumab for the treatment of patients with moderately to severely active psoriatic arthritis: results of a double-blind, randomized, placebocontrolled trial. Arthritis Rheum 2005; 52:3279-89.

59. Mease P.J., P. Ory, J.T. Sharp et al. Adalimumab for long-term treatment of psoriatic arthritis: 2-year data from the Adalimumab Effectiveness in Psoriatic Arthritis Trial (ADEPT). Ann Rheum Dis 2009; 68:702-9.

60. Menter A., S.K. Tyring, K. Gordon et al. Adalimumab therapy for moderate to severe psoriasis: A randomized, controlled phase III trial. J Am Acad Dermatol 2008; 58:106-15.

61. Gordon K., K. Papp, Y. Poulin, Y. Gu, S. Rozzo, E.H. Sasso. Long-term efficacy and safety of adalimumab in patients with moderate to severe psoriasis treated continuously over 3 years: results from an open-label extension study for patients from REVEAL. J Am Acad Dermatol 2012; 66:241-51.

62. Saurat J.H., G. Stingl, L. Dubertret et al. Efficacy and safety results from the randomized controlled comparative study of adalimumab vs. methotrexate vs. placebo in patients with psoriasis (CHAMPION). Br J Dermatol 2008; 158:558-66.

63. Colombel J.F., W.J. Sandborn, P. Rutgeerts et al. Adalimumab for maintenance of clinical response and remission in patients with Crohn's disease: the CHARM trial. Gastroenterology 2007; 132:52-65.

64. Schreiber S., W. Reinisch, J.F. Colombel et al.
Subgroup analysis of the placebo-controlled CHARM trial: increased remission rates through 3 years for adalimumab-treated patients with early Crohn's disease. J Crohns Colitis 2013; 7:213-21.

65. Sandborn W.J., S.B. Hanauer, P. Rutgeerts et al. Adalimumab for maintenance treatment of Crohn's disease: results of the CLASSIC II trial. Gut 2007; 56:1232-9.

66. Rutgeerts P., G. Van Assche, W.J. Sandborn et al. Adalimumab induces and maintains mucosal healing in patients with Crohn's disease: data from the EXTEND trial. Gastroenterology 2012; 142:1102-11 e2.

67. Sandborn W.J., G. van Assche, W. Reinisch et al. Adalimumab induces and maintains clinical remission in patients with moderate-to-severe ulcerative colitis. Gastroenterology 2012; 142:25765 e $1-3$.

68. Sandborn W.J., J.F. Colombel, G. D'Haens et al. One-year maintenance outcomes among patients with moderately-to-severely active ulcerative colitis who responded to induction therapy with adalimumab: subgroup analyses from ULTRA 2. Aliment Pharmacol Ther 2013; 37:204-13.

69. Garcia-Bosch O., J.P. Gisbert, A. Canas-Ventura et al. Observational study on the efficacy of adalimumab for the treatment of ulcerative colitis and predictors of outcome. J Crohns Colitis 2013; 7:717-722.

70. D'Haens G., W. Reinisch, J. Satsangi et al. PYRAMID Registry: Observational Study of Adalimumab in Crohn's Disease: Results at Year 3 [poster P1140]. The American College of Gastroenterology Annual Scientific Meeting Washington, DC 2011.

71. Armuzzi A., L. Biancone, M. Daperno et al. Adalimumab In Active Ulcerative Colitis: A "RealLife" Observational Study. Dig Liver Dis 2013; 45:738-43.

72. Afif W., J.A. Leighton, S.B. Hanauer et al. Openlabel study of adalimumab in patients with ulcerative colitis including those with prior loss of response or intolerance to infliximab. Inflamm Bowel Dis 2009; 15:1302-7.

73. Baert F., E. Glorieus, C. Reenaers et al. Adalimumab dose escalation and dose de-escalation success rate and predictors in a large national cohort of Crohn's patients. J Crohns Colitis 2013; 7:154-60. 
74. Kleinert S.. H.P. Tony, A. Krause et al. Impact of patient and disease characteristics on therapeutic success during adalimumab treatment of patients with rheumatoid arthritis: data from a German noninterventional observational study. Rheumatol Int 2012; 32:2759-67.

75. Bombardieri S., A.A. Ruiz, P. Fardellone et al. Effectiveness of adalimumab for rheumatoid arthritis in patients with a history of TNF-antagonist therapy in clinical practice. Rheumatology (Oxford) 2007; 46:1191-9.

76. Burmester G.R., X. Mariette, C. Montecucco et al. Adalimumab alone and in combination with diseasemodifying antirheumatic drugs for the treatment of rheumatoid arthritis in clinical practice: the Research in Active Rheumatoid Arthritis (ReAct) trial. Ann Rheum Dis 2007; 66:732-9.

77. Papp K., J. Crowley, J.P. Ortonne et al. Adalimumab for moderate to severe chronic plaque psoriasis: efficacy and safety of retreatment and disease recurrence following withdrawal from therapy. $\mathrm{Br} \mathrm{J}$ Dermatol 2011; 164:434-41.

78. Taniguchi T., S. Noda, N. Takahashi, H. Yoshimura, K. Mizuno, M. Adachi. An observational, prospective study of monthly adalimumab therapy for disease maintenance in psoriasis patients: a possible new therapeutic option for good responders to the initial induction treatment. J Eur Acad Dermatol Venereol 2013; 27:1444-1447..

79. Zavada J., W.G. Dixon, J. Askling. Launch of a checklist for reporting longitudinal observational drug studies in rheumatology: a EULAR extension of STROBE guidelines based on experience from biologics registries. Ann Rheum Dis 2014; 73:628.

80. Caporali R., F.B. Pallavicini, M. Filippini et al. Treatment of rheumatoid arthritis with anti-TNFalpha agents: a reappraisal. Autoimmun Rev 2009; 8:274-80.

81. Mariette X., J.E. Gottenberg, P. Ravaud, B. Combe. Registries in rheumatoid arthritis and autoimmune diseases: data from the French registries. Rheumatology (Oxford) 2011; 50:222-9.

82. de Punder Y.M., J. Fransen, W. Kievit, P.M. Houtman, H. Visser, M.A. van de Laar, P.L. van Riel. The prevalence of clinical remission in RA patients treated with anti-TNF: results from the
Dutch Rheumatoid Arthritis Monitoring (DREAM) registry. Rheumatology (Oxford) 2012; 51:1610-7.

83. van Dartel S.A., J. Fransen, W. Kievit et al. Difference in the risk of serious infections in patients with rheumatoid arthritis treated with adalimumab, infliximab and etanercept: results from the Dutch Rheumatoid Arthritis Monitoring (DREAM) registry. Ann Rheum Dis 2013; 72:895-900.

84. van Dartel S.A., J. Fransen, W. Kievit et al. Predictors for the 5-year risk of serious infections in patients with rheumatoid arthritis treated with antitumour necrosis factor therapy: a cohort study in the Dutch Rheumatoid Arthritis Monitoring (DREAM) registry. Rheumatology (Oxford) 2013; 52:1052-7.

85. Hetland M.L., I.J. Christensen, U. Tarp et al. Direct comparison of treatment responses, remission rates, and drug adherence in patients with rheumatoid arthritis treated with adalimumab, etanercept, or infliximab: results from eight years of surveillance of clinical practice in the nationwide Danish DANBIO registry. Arthritis Rheum 2010; 62:22-32.

86. Ornbjerg L.M., M. Ostergaard, P. Boyesen et al. Impact of tumour necrosis factor inhibitor treatment on radiographic progression in rheumatoid arthritis patients in clinical practice: results from the nationwide Danish DANBIO registry. Ann Rheum Dis 2013; 72:57-63.

87. Atzeni F., P. Sarzi-Puttini, C. Botsios et al. Longterm anti-TNF therapy and the risk of serious infections in a cohort of patients with rheumatoid arthritis: comparison of adalimumab, etanercept and infliximab in the GISEA registry. Autoimmun Rev 2012; 12:225-9.

88. Iannone F., E. Gremese, F. Atzeni et al. Longterm retention of tumor necrosis factor-alpha inhibitor therapy in a large italian cohort of patients with rheumatoid arthritis from the GISEA registry: an appraisal of predictors. J Rheumatol 2012; 39:1179-84.

89. Furst D.E., A.L. Pangan, L.R. Harrold, H. Chang, G. Reed, J.M. Kremer, J.D. Greenberg. Greater likelihood of remission in rheumatoid arthritis patients treated earlier in the disease course: results from the Consortium of Rheumatology Researchers of North America registry. Arthritis Care Res (Hoboken) 2011; 63:856-64.

90. Greenberg J.D., G. Reed, D. Decktor et al. A 
comparative effectiveness study of adalimumab, etanercept and infliximab in biologically naive and switched rheumatoid arthritis patients: results from the US CORRONA registry. Ann Rheum Dis 2012; 71:1134-42.

91. Markenson J.A., A. Gibofsky, W.R. Palmer, E.C. Keystone, M.H. Schiff, J. Feng, S.W. Baumgartner. Persistence with anti-tumor necrosis factor therapies in patients with rheumatoid arthritis: observations from the RADIUS registry. J Rheumatol 2011; 38:1273-81.

92. Hyrich K.L., K.D. Watson, D.A. Isenberg, D.P. Symmons. The British Society for Rheumatology Biologics Register: 6 years on. Rheumatology (Oxford) 2008; 47:1441-3.

93. Lunt M., K.D. Watson, W.G. Dixon, D.P. Symmons, K.L. Hyrich. No evidence of association between anti-tumor necrosis factor treatment and mortality in patients with rheumatoid arthritis: results from the British Society for Rheumatology Biologics Register. Arthritis Rheum 2010; 62:3145-53.

94. Saad A.A., D.M. Ashcroft, K.D. Watson, K.L. Hyrich, P.R. Noyce, D.P. Symmons. Persistence with anti-tumour necrosis factor therapies in patients with psoriatic arthritis: observational study from the British Society of Rheumatology Biologics Register. Arthritis Res Ther 2009; 11:R52.

95. Lord P.A., T.M. Farragher, M. Lunt, K.D. Watson, D.P. Symmons, K.L. Hyrich. Predictors of response to anti-TNF therapy in ankylosing spondylitis: results from the British Society for Rheumatology Biologics Register. Rheumatology (Oxford) 2010; 49:563-70.

96. McErlane F., H.E. Foster, R. Davies, M. Lunt, K.D. Watson, D.P. Symmons, K.L. Hyrich. Biologic treatment response among adults with juvenile idiopathic arthritis: results from the British Society for Rheumatology Biologics Register. Rheumatology (Oxford) 2013; 52:1905-13.

97. Lichtenstein G.R., B.G. Feagan, R.D. Cohen et al. Serious infection and mortality in patients with Crohn's disease: more than 5 years of follow-up in the TREAT registry. Am J Gastroenterol 2012; 107:1409-22.

98. Gisondi P., S. Cazzaniga, S. Chimenti et al. Metabolic abnormalities associated with initiation of systemic treatment for psoriasis: evidence from the Italian
Psocare Registry. J Eur Acad Dermatol Venereol 2013; 27:e30-41.

99. Spandonaro F., G. Altomare, E. Berardesca et al. Health-related quality of life in psoriasis: an analysis of Psocare project patients. G Ital Dermatol Venereol 2011; 146:169-77.

100. Prignano F., L. Pescitelli, F. Ricceri, T. Lotti. Retrospective analysis of systemic treatments for psoriasis patients attending a Psocare center in Florence. Relevance of biological drugs use and comorbidities. J Eur Acad Dermatol Venereol 2010; 24:555-60.

101. Nijsten T., M. Wakkee. Psocare: Italy shows the way in postmarketing studies. Dermatology 2008; 217:362-4.

102. Naldi L., A. Addis, S. Chimenti et al. Impact of body mass index and obesity on clinical response to systemic treatment for psoriasis. Evidence from the Psocare project. Dermatology 2008; 217:365-73.

103. Halpern M.T., M.A. Cifaldi, T.K. Kvien. Impact of adalimumab on work participation in rheumatoid arthritis: comparison of an open-label extension study and a registry-based control group. Ann Rheum Dis 2009; 68:930-7.

104. Kavanaugh A., R.M. Fleischmann, P. Emery et al. Clinical, functional and radiographic consequences of achieving stable low disease activity and remission with adalimumab plus methotrexate or methotrexate alone in early rheumatoid arthritis: 26-week results from the randomised, controlled OPTIMA study. Ann Rheum Dis 2013; 72:64-71.

105. Combe B., R. Landewe, C. Lukas et al. EULAR recommendations for the management of early arthritis: report of a task force of the European Standing Committee for International Clinical Studies Including Therapeutics (ESCISIT). Ann Rheum Dis 2007; 66:34-45.

106. Epis O.M., L. Giacomelli, S. Deidda, E. Bruschi. Tight control applied to the biological therapy of rheumatoid arthritis. Autoimmun Rev 2013; 12:839-41.

107. Nusslein H.G. [How early would we really administer biologics?]. Z Rheumatol 2012; 71:838-9.

108. Bouguen G., B.G. Levesque, B.G. Feagan et al. Treat to Target: A Proposed New Paradigm for the Management of Crohn's Disease. Clin Gastroenterol Hepatol 2013; pii:S1542-3565. 
109. Kooloos W.M., D.J. de Jong, T.W. Huizinga, H.J. Guchelaar. Potential role of pharmacogenetics in antiTNF treatment of rheumatoid arthritis and Crohn's disease. Drug Discov Today 2007; 12:125-31.

110. Morales-Lara M.J., J.D. Canete, D. Torres-Moreno et al. Effects of polymorphisms in TRAILRI and TNFR1A on the response to anti-TNF therapies in patients with rheumatoid and psoriatic arthritis. Joint Bone Spine 2012; 79:591-6. Bone Spine 2012; 79:591-6. 